\title{
Influence of infant feeding and gluten intake on coeliac disease
}

\author{
H Ascher, I Krantz, L Rydberg, P Nordin, B Kristiansson
}

\begin{abstract}
Objectives-To study the impact of infant feeding habits and actual gluten intake on gluten induced enteropathy.

Methods-A case-referent design, controlling for the HLA alleles conferring increased genetic risk, was used. All 164 siblings of 97 probands were investigated. Eighty five of the siblings, carrying the genes DQA1*0501-DQB1*02 conferring susceptibility for the disease, were investigated by interview, food recording, and taking a small intestinal biopsy sample. Eight cases of silent coeliac disease were found and these were compared with the 73 siblings in whom the diagnosis was excluded.

Results-No statistically significant differences were found between cases and referents in terms of duration of breast feeding, age at introduction of cows' milk products, frequency of breast feeding after gluten introduction, and gluten consumption.

Conclusions-The studied factors may be of less importance for the development of gluten induced enteropathy.

(Arch Dis Child 1997;76:113-117)
\end{abstract}

Keywords: coeliac disease; HLA alleles; infant feeding habits; gluten consumption.

Department of Paediatrics, Göteborg University, East University Hospital, Göteborg, Sweden $\mathrm{H}$ Ascher

B Kristiansson

Nordic School of Public Health, Göteborg, Sweden I Krantz

P Nordin

The Regional Blood Centre, Göteborg University,

Sahlgrenska University

Hospital, Göteborg,

Sweden

L Rydberg

Correspondence to: Dr Henry Ascher,

Department of Paediatrics, Göteborg University, East

University Hospital, S-416

85 Göteborg, Sweden.

Accepted 26 September 1996
There are at least two prerequisites for developing coeliac disease: a genetic predisposition and gluten intake. So far, two HLA alleles on chromosome 6 have been shown to confer a primary susceptibility. ${ }^{1}$ These alleles encode the heterodimer $\operatorname{DQ}\left(\alpha 1^{\star} 0501, \beta 1^{\star} 02\right)$, found in $80-100 \%$ of patients with coeliac disease $^{2}$ and corresponding to the serological HLA type DR3-DQ2 or DR5/7-DQ2, considered as the HLA haplotypes at risk for coeliac disease.

Most people who carry these genes do not develop coeliac disease, however, despite gluten intake. It therefore seems probable that additional genes, as yet unknown, are involved or that other factors are of importance. The duration of breast feeding, the age at which gluten is introduced into the infant diet, the duration of the period when both breast milk and gluten are given, the amount of gluten consumed, and infectious agents are environmental factors suggested to be of importance. ${ }^{3}$

Sweden, in contrast with its neighbouring countries, ${ }^{45}$ has had an increasing incidence of coeliac disease during the last decades, particularly in children born after $1982 .{ }^{67}$ In the search for an explanation, interest has mainly been focused on infant feeding patterns for two reasons: the infant feeding habits in Sweden are different to those in neighbouring countries, and the increase in incidence has occurred during a period when infant feeding patterns have changed. ${ }^{89}$ Whether these changes have caused genetically less susceptible subjects to develop coeliac disease or if they have led to more obvious symptoms in children with existing gluten induced enteropathy is discussed. ${ }^{10-12}$

The aim of this study was to analyse the impact of early infant feeding habits and actual gluten intake on gluten induced enteropathy by controlling for the HLA alleles considered as an expression of the genetic risk.

\section{Patients and methods}

A case-referent design was applied in the study using the siblings of patients verified as having coeliac disease. Only siblings with DR3-DQ2 or DR5/DR7-DQ2 were included to match for genetic risk factors. The cases were defined as siblings with previously unknown coeliac disease and the referents as siblings without coeliac disease.

\section{PATIENTS}

An overview of the study design is shown in fig 1 . The selection was made in the following way. A letter of invitation was sent to the 268 families of 272 patients with coeliac disease living in the area, the coeliac disease having been diagnosed between 1970 and 1991 at the department of paediatrics, East University Hospital, Göteborg. The family was included only if (a) the proband was diagnosed according to the original ESPGAN criteria, ${ }^{13}$ (b) he or she had at least one full sibling older than 6 months without diagnosed coeliac disease, and (c) both parents were available for HLA testing. Of the 268 families, 159 families with 160 patients and 234 siblings fulfilled the inclusion criteria, whereas 84 families did not. Whether the remaining 25 families fulfilled the criteria is unclear as they did not answer the letter of invitation.

Ninety six families with 97 probands and 164 siblings, including three families with three probands and four siblings from the vicinity of Göteborg who approached us spontaneously and requested participation, were enrolled in the study (fig 1). All family members were tested for HLA class I and II antigens and serological coeliac disease markers (see later). At the same time the families were instructed to ensure that the siblings were eating normal 


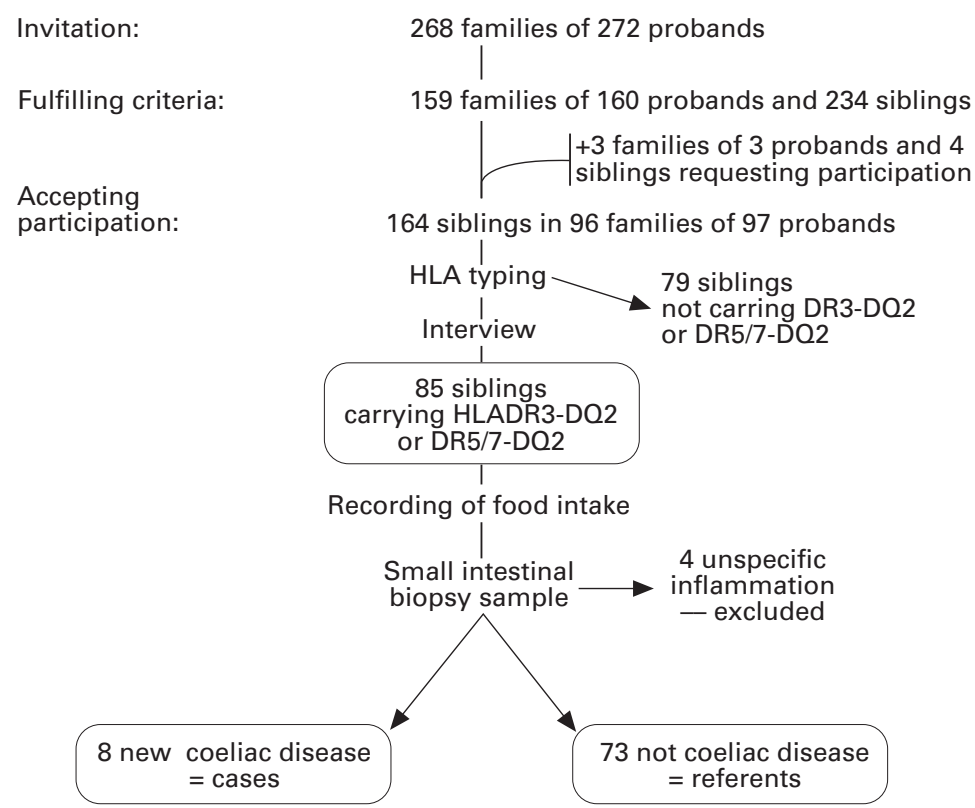

Figure 1 Overview of the design of the study.

gluten containing foods. Eighty five siblings in 66 families carried the HLA genotypes DR3DQ2/DR3-DQ2, DR3-DQ2/x (where $\mathrm{x}$ are configurations other than DR3-DQ2) or DR5/ DR7-DQ2, whereas 79 did not and were excluded from further study. The mothers were interviewed and a small intestinal biopsy sample was taken from 82 siblings, preceded by a four day recording of food intake. Of the remaining three siblings, one had had a small intestinal biopsy sample taken previously showing normal mucosa, and two siblings dropped out from the study. Of the 79 siblings who did not carry any of the HLA risk alleles, 35 of 36 who shared other HLA haplotypes with their proband sibling had a small intestinal biopsy sample taken as they were expected to have an increased genetic risk. The intestinal mucosa was normal in all instances. All but one of the 79 siblings were negative in serological markers for coeliac disease and were considered to be healthy. The only boy with slightly increased antibodies to gliadin later had a small intestinal biopsy sample taken which showed a normal mucosa.

Eight cases were found with an intestinal mucosa compatible with coeliac disease (table 1). The referent group (73 subjects) consisted of 61 siblings with a normal intestinal histology, the one sibling who previously had a normal small intestinal biopsy sample taken, and the two siblings with normal serological markers for coeliac disease who dropped out of the study. Of 13 siblings with various degrees of mucosal inflammation but normal villus height and crypt depth, nine became normal histologically in spite of increased gluten intake. They were accordingly included in the referent group. The final diagnosis of the remaining four of the 13 siblings with slight histological changes remained unclear and they were excluded from further analysis.

Table 1 Characteristics of the cases

\begin{tabular}{|c|c|c|c|c|c|c|c|c|c|c|c|c|c|}
\hline $\begin{array}{l}\text { Patient } \\
\text { No }\end{array}$ & $\begin{array}{l}\text { Birth } \\
\text { year }\end{array}$ & $\begin{array}{l}\text { Age when } \\
\text { small } \\
\text { intestinal } \\
\text { biopsy sample } \\
\text { taken (years) }\end{array}$ & $\operatorname{Sex}$ & $\begin{array}{l}H L A \\
\text { class II }\end{array}$ & $\begin{array}{l}\text { Duration of } \\
\text { breast } \\
\text { feeding } \\
\text { (months) }\end{array}$ & $\begin{array}{l}\text { Age at } \\
\text { cows' milk } \\
\text { introduction } \\
\text { (months) }\end{array}$ & $\begin{array}{l}\text { Age at } \\
\text { gluten } \\
\text { introduction } \\
\text { (months) }\end{array}$ & $\begin{array}{l}\text { Duration of } \\
\text { mixed } \\
\text { breast } \\
\text { milk-gluten } \\
\text { feeding } \\
\text { (months) }\end{array}$ & $\begin{array}{l}\text { Wheat } \\
\text { protein } \\
\text { consumption } \\
\text { at time of } \\
\text { small } \\
\text { intestinal } \\
\text { biopsy sample } \\
\text { (g/kg/day) }\end{array}$ & $E M A$ & $\begin{array}{l}A G A \\
I g G\end{array}$ & $\begin{array}{l}A G A \\
I g A\end{array}$ & $\begin{array}{l}\text { Symptoms } \\
\text { given in } \\
\text { parental } \\
\text { interview }\end{array}$ \\
\hline 1 & 1990 & 3.2 & $\mathrm{~F}$ & $\begin{array}{l}\text { DR3-DQ2/ } \\
\text { DR4-DQ3 }\end{array}$ & 5 & 3 & 6 & 0 & 0.24 & Positive & Positive & Negative & None \\
\hline 2 & 1988 & 5.7 & $\mathrm{~F}$ & $\begin{array}{l}\mathrm{DR} 2-\mathrm{DQ} 1 / \\
\mathrm{DR} 3-\mathrm{DQ} 2\end{array}$ & 9 & 6 & 6 & 3 & 0.14 & Positive & Positive & Negative & $\begin{array}{l}\text { Constipation, } \\
\text { eczema }\end{array}$ \\
\hline 3 & 1987 & 6.4 & $\mathrm{~F}$ & $\begin{array}{l}\text { DR3-DQ2/ } \\
\text { DR4-DQ3 }\end{array}$ & 7.5 & 4 & 6 & 1.5 & 0.36 & Positive & Negative & Negative & $\begin{array}{l}\text { Previous } \\
\text { abdominal } \\
\text { protrusion } \\
\text { and suspected } \\
\text { cows' milk } \\
\text { intolerence }\end{array}$ \\
\hline 4 & 1985 & 7.4 & M & $\begin{array}{l}\text { DR1-DQ1/ } \\
\text { DR3-DQ2 }\end{array}$ & 1.5 & 1.5 & 5 & 0 & 0.07 & Positive & ND & ND & $\begin{array}{l}\text { Constipation, } \\
\text { DAMP, } \\
\text { delayed } \\
\text { development }\end{array}$ \\
\hline 5 & 1986 & 7.8 & $M$ & $\begin{array}{l}\text { DR2-DQ1/ } \\
\text { DR3-DQ2 }\end{array}$ & 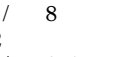 & 3.5 & 6 & 2 & 0.27 & Positive & ND & ND & None \\
\hline 6 & 1984 & 9.1 & $\mathrm{~F}$ & $\begin{array}{l}\text { DR3-DQ2/ } \\
\text { DR6-DQ1 }\end{array}$ & 3.5 & 3 & 5 & 0 & 0.11 & Positive & ND & ND & $\begin{array}{l}\text { Previous } \\
\text { diarrhoea, } \\
\text { headache and } \\
\text { abdominal } \\
\text { protrusion }\end{array}$ \\
\hline 7 & 1980 & 13.4 & $\mathrm{~F}$ & $\begin{array}{l}\text { DR3-DQ2/ } \\
\text { DR7-DQ2 }\end{array}$ & 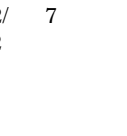 & 5 & 6 & 1 & 0.25 & Positive & ND & ND & $\begin{array}{l}\text { Sporadic } \\
\text { constipation } \\
\text { and } \\
\text { abdominal } \\
\text { pain }\end{array}$ \\
\hline 8 & 1976 & 17.7 & $\mathrm{~F}$ & $\begin{array}{l}\text { DR1-DQ1/ } \\
\text { DR3-DQ2 }\end{array}$ & 6 & 4 & 5 & 1 & 0.14 & Positive & ND & ND & $\begin{array}{l}\text { Diffuse } \\
\text { abdominal } \\
\text { complaints } \\
\text { Previous } \\
\text { diarrhoea, } \\
\text { vomiting, } \\
\text { abdominal } \\
\text { pain }\end{array}$ \\
\hline
\end{tabular}


Table 2 Early feeding pattern and actual gluten intake in cases and referents

\begin{tabular}{|c|c|c|c|c|c|c|}
\hline & \multicolumn{3}{|l|}{ Cases } & \multicolumn{3}{|l|}{ Referents } \\
\hline & Median & Range & No & Median & Range & No \\
\hline Duration of breast feeding (months) & 6.5 & $1.5-9.0$ & 8 & 5.0 & $0-14.0$ & 73 \\
\hline Age at introduction of foods containing cows' milk (months) & 4.0 & $1.5-6.0$ & 7 & 3.0 & $0-9.0$ & 73 \\
\hline Age at introduction of foods containing gluten (months) & 6.0 & $5.0-6.0$ & 8 & 6.0 & $3.5-6.0$ & 72 \\
\hline $\begin{array}{l}\text { Consumption of wheat protein at the time of biopsy sample } \\
(\mathrm{g} / \mathrm{kg} / \mathrm{day})\end{array}$ & 0.19 & $0.07-0.36$ & 8 & 0.27 & $0.06-0.54$ & 66 \\
\hline
\end{tabular}

HLA TYPING

$\mathrm{T}$ and $\mathrm{B}$ lymphocytes were prepared from 10 $\mathrm{ml}$ of a mixture of EDTA and blood by immunomagnetic separation. ${ }^{14}$ HLA class I and II types were determined by serology using a microlymphocytotoxic technique. Each specificity was assigned by several well defined antisera. The same typing trays were used during the whole investigation.

\section{INTERVIEW}

After pilot testing one specially trained children's nurse performed a semistructured interview with the mother of each family in their own home environment at a time selected by the mother. The result of the HLA typing was not known either by the mother or the interviewer at the time of the interview. The questions aimed to assess the duration of breast feeding, the age at which cows' milk and gluten containing foods were introduced, and, when relevant, the occurrence of symptoms for each child in the family. The answers were categorised and recorded by the interviewer.

FOOD RECORDING

After receiving instructions, food recordings were made during four days by the parents or the adolescent patients under study. All foods and beverages given, measured with household measures, were included. ${ }^{15}$ The amount of gluten containing cereals (wheat, rye, oats, and barley) was calculated by one paediatric dietician by the same method as in a previous study. ${ }^{9}$

SMALL INTESTINAL BIOPSY SAMPLE

A small intestinal biopsy sample was taken (preferably at the level of the Treitz ligament) with a Watson capsule (paediatric size) or a Storz capsule under fluoroscopic control by one of us (HA). The specimens were handled and classified as previously described ${ }^{16}$ and read by the same experienced pathologist.

SEROLOGICAL MARKERS

All parents and siblings were tested for total IgA and antibodies to endomysium of IgA class in the serum. ${ }^{17}$ Children less than 5 years of age were also tested for the presence of IgA and IgG class antibodies to gliadin. ${ }^{18}$

STATISTICAL METHODS

For the statistical evaluation of the differences between cases and referents, Fisher's exact test in fourfold tables and, where appropriate, the $\chi^{2}$ test were used. As the infant feeding pattern and gluten consumption were not normally distributed, median values and Wilcoxon's two sample test were used instead.
ETHICS

The study was approved by the ethical committee of the Faculty of Medicine at Göteborg University. Several reasons justified the use of taking a small intestinal biopsy sample in the protocol. No serological marker in coeliac disease has a $100 \%$ sensitivity and antibodies to endomysium have a lower sensitivity in the youngest age groups. ${ }^{17}{ }^{19}$ In addition, these tests have mainly been evaluated in patients with symptoms and the results could not simply be extrapolated to this study investigating subjects without symptoms. In spite of improved serological markers for coeliac disease, a small intestinal biopsy sample therefore remains the golden standard for the diagnosis. ${ }^{20}$

As the long term health risks with untreated coeliac disease are mainly related to the state of the mucosa rather than the existence or severity of symptoms, ${ }^{21}$ the study offered benefits for the siblings under study in identifying undiagnosed coeliac disease.

\section{Results}

The median age at the time at which the small intestinal biopsy sample was taken was 7.9 years for the cases (range 3.2-17.9) and 7.4 years for the referents $(0.92-25.0$; NS). Seventy five per cent of the cases and $59 \%$ of the referents were girls. Fifty per cent of the cases were the first born child of the family, compared with $38 \%$ of the referents (NS) and $63 \%$ of the cases were born before their proband compared with $51 \%$ of the referents (NS).

Compared with the referents, the cases had a longer duration of breast feeding (NS), a later introduction of foods containing cows' milk (table 2) (NS), as well as a higher frequency of breast feeding during the introduction of gluten containing follow up formulas (table 3) (NS) and a lower consumption of gluten at the time the small intestinal biopsy sample was taken (table 2) ( $p=0.07$; NS). Two of 26 siblings $(8 \%)$ born before 1982, when the recommended age for gluten introduction changed from 4 to 6 months and the gluten content in the baby foods increased, had coeliac disease, compared with six of $51(12 \%)$ of those born after that year (NS).

The risk for coeliac disease was 5.5\% (9/165, the previously diagnosed case included) in all siblings and $10.6 \%(9 / 85)$ in siblings carrying the HLA risk allele.

\section{Discussion}

Since the method of taking a small intestinal biopsy sample was introduced, a number of sibling studies of coeliac disease have been performed, ${ }^{22-33}$ but only a few have also investi- 
Table 3 The relation of breast feeding and introduction of gluten containing follow up formulas

\begin{tabular}{lll}
\hline & No (\%) cases $(n=8)$ & No (\%) referents $(n=73)$ \\
\hline $\begin{array}{l}\text { Breast feeding continued during introduction } \\
\begin{array}{l}\text { Breast feeding discontinued at time of } \\
\text { introduction }\end{array}\end{array}$ & $5(63)$ & $25(34)$ \\
Breast feeding discontinued before introduction & $3(37)$ & $13(18)$ \\
\hline
\end{tabular}

gated the infant feeding pattern. ${ }^{23}{ }^{31}$ The present study is the first which has tried to study the influence of this factor and the actual gluten consumption on coeliac disease matching for a genetic risk.

The reason for using a family design was that we could expect to find both a sufficient number of cases and genetically matched referents within a study group of a reasonable size. A population study, which theoretically would be advantageous, would need a sample size practically and ethically difficult to justify.

Previous studies indicated an expected overall risk for coeliac disease in siblings to coeliac disease patients of $10 \%$, increasing to $28-40 \%$ in HLA identical or DR3 positive siblings. ${ }^{34-36}$ We could only find eight new cases, however, which together with the already diagnosed sibling corresponded to an overall risk of $5.5 \%$ or $10.5 \%$ in HLA identical or DR3-DQ2 or DR5/DR7-DQ2 positive siblings. One possible explanation for these variances might be different selections.

A selection bias may have worked on two levels. Firstly, if families with symptomatic children are more prone to participate in studies, this would result in a falsely higher prevalence in studies with a low participation rate. Except for the studies by Rolles et $a l^{29}$ and Stenhammar et $a l,{ }^{31}$ who studied the parents and families, respectively, of consecutive cases, it is difficult to identify the number invited and the selection procedures used in previous family studies. In our study, all patients with coeliac disease available at our department were invited and $61 \%$ of the patients fulfilling the inclusion criteria agreed to participate.

Secondly, in many studies the figures for the sibling frequency are calculated by dividing the number of new cases by the number of biopsy samples taken rather than by all the siblings included. This makes the result vulnerable to the selection procedure for taking the small intestinal biopsy sample. A higher rate of acceptance among relatives with decreased wellbeing has to be expected and a falsely high prevalence in studies with a low sample rate for the small intestinal biopsy sample could be the effect. An analysis of the nine studies, ${ }^{22-25} 27$ 29-31 including this study, in which the necessary figures were available did show a strong negative correlation between the occurrence (number of new cases of coeliac disease per number of biopsy samples) and the frequency of small intestinal biopsy samples (number of biopsy samples per total number of siblings). When the frequency was calculated as a prevalence - that is, the number of new cases divided by the total number of siblings-no such association was found and the prevalence was $6.5 \% \quad(50 / 769$, already known cases included) with a corresponding 95\% confidence interval of 4.8 to 8.2 - that is, about half of that which has generally been believed. This figure is in accordance with the results of our study.

A factor that may be of importance for the development of gluten induced enteropathy is the duration of gluten exposure. As the time at risk is relatively short in our study, the prevalence may increase in the future. On the other hand, if this factor was important, a higher age in the cases than in the referents would be expected.

Early termination of breast feeding has been found to be a risk factor for diagnosed - that is, symptomatic - patients with coeliac disease in previous studies. ${ }^{37}$ The early introduction of cows' milk or gluten containing foods, the termination of breast feeding before the introduction of gluten, and a high consumption of gluten have also been hypothesised as risk factors. In this study we found no support for these theories. The duration of breast feeding was long compared with patterns in other Western countries, both in the cases and referents. No significant differences in the feeding patterns were found between the cases and referents. The tendency was rather towards a longer duration of breast feeding, a later introduction of formulas containing cows' milk, more mixed breast and gluten feeding, and a lower gluten consumption in the cases. The latter might be an effect of a spontaneous reduction in the gluten consumption to avoid symptoms. It might be suspected that both cases and referents normally consume low amounts of gluten as they have siblings on a gluten free diet. According to our data, however, they consumed 0.28 and $0.34 \mathrm{~g}$ of flour protein/kg body weight/day (wheat, rye, oats, and barley), which can be compared with the consumption of approximately $0.27 \mathrm{~g} / \mathrm{kg}$ body weight/day in Swedish adults with newly diagnosed dermatitis herpetiformis before dietary treatment. ${ }^{39}$

Various explanations for the lack of differences between the cases and referents found in this study can be suggested. Firstly, the studied populations are different. Most previous studies on early infant feeding and coeliac disease have been made on diagnosed-that is, symptomatic-cases whereas we investigated patients with 'silent'-that is, more or less asymptomatic-coeliac disease. The factors under study may have an effect on the symptoms of coeliac disease rather than on the enteropathy itself. ${ }^{40}$ Even if most of the cases in our study had some symptoms (table 1), they were so discrete that the parents had not suspected them to be caused by coeliac disease in spite of the awareness of the disease in these families. Secondly, the unexpectedly low number of cases in our study might result in biologically significant differences remaining statistically insignificant. For any study of this type obtaining a sufficient number of cases is a problem. Meta-analysis may be a solution to this problem.

On the other hand, the lack of statistical significance may indicate that the factors studied are actually of less importance for the develop- 
ment of gluten induced enteropathy. In addition, if environmental conditions were more important than genetic predisposition in determining the occurrence of coeliac disease, a higher prevalence of the disease among relatives would be expected in a high incidence area, such as Sweden, compared with areas with a lower incidence. ${ }^{41}$ The low prevalence of coeliac disease in siblings found in this study as well as in the whole group of patients with coeliac disease in Göteborg therefore suggests that genetic factors, most probably factors besides $\mathrm{DQA} 1{ }^{\star} 0501$ and $\mathrm{DQB} 1{ }^{\star} 02$ and as yet unknown, are of greater importance for determining the prevalence of gluten induced enteropathy than environmental factors, which may play a more important part in the clinical expression of the disease..$^{1112}$

The study was supported by grants from the Wilhelm and Martina Lundgren Foundation, the Göteborg Medical Society, the First of May Flower Annual Campaign for Children's Health 'Förenade Liv' Mutual Group Life Insurance Company, 'Samariten' foundation, the Swedish Coeliac Disease Association, the Royal Society of Arts and Sciences in Gothenburg, Sweden, and the Swedish Society for Medical Research.

We express our special thanks to the children and parents participating in the study, to Britt-Marie Käck, paediatric nurse, who masterly carried out the blood sample collection and arranged all practical details, to Eva Persson who performed the interviews and to Ingrid Odenman, paediatric dietitian, who skilfully carried out the calculations on infant feeding.

1 Sollid LM, Markussen G, Ek J, Gjerde H, Vartdal F, Thorsby E. Evidence for a primary association of celiac disease to a particular HLA-DQ $\alpha / \beta$ heterodimer. $\mathcal{F}$ Exp Med 1989;169:345-50

2 Sollid LM, Thorsby E. HLA susceptibility genes in celiac disease: genetic mapping and role in pathogenesis. Gastrodisease: genetic mapping and

3 Mäki M, Holm K, Ascher H, Greco L. Factors affecting clinical presentation of coeliac disease: role of type and amount of gluten-containing cereals in the diet. In: Auricchio S, Visakorpi J, eds. Common food intolerances 1: epidemiology of coeliac disease. Basle: Karger, 1992:76-82.

4 Mäki M, Holm K. Incidence and prevalence of coeliac disease in Tampere. Coeliac disease is not disappearing. Acto Paediatr Scand 1990;79:980-2.

5 Weile B, Krasilnikoff PA. Low incidence rates by birth of symptomatic coeliac disease in a Danish population of children. Acta Paediatr 1992;81:394-8.

6 Ascher H, Krantz I, Kristiansson B. Increasing incidence of coeliac disease in Sweden. Arch Dis Child 1991;66:608-11.

7 Cavell B, Stenhammar L, Ascher $\mathrm{H}$, et al. Increasing incidence of childhood coeliac disease in Sweden. Results of a national study. Acta Paediatr 1992;81:589-92.

8 Kristiansson B, Ascher H, Odenman I, Sandberg L. The incidence of coeliac disease and changes in gluten incidence of coeliac disease and changes in gluten disease-40 years gluten-free diet. Dordrecht: Kluwer Acadisease-40 years gluten-
demic, $1991: 107-14$.

9 Ascher H, Holm K, Kristiansson B, Mäki M. Different features of coeliac disease in two neighbouring countries. Arch Dis Child 1993;69:375-80.

10 Juto P, Meeuwisse G, Mincheva-Nilsson L. Why has coeliac disease increased in Swedish children? Lancet 1994;343 1372.

11 Ascher H, Kristiansson B. Childhood coeliac disease in Sweden. Lancet 1994;344:340-1.

12 Stenhammar L. Childhood coeliac disease in Sweden. Lancet 1994;344:341-2.

13 Meeuwisse GW. Diagnostic criteria in coeliac disease. Acta Paediatr Scand 1970;59:461-3.

14 Vartdal F, Gaudernack G, Funderud S, et al. HLA class I and II typing using cells positively selected from blood by immunomagnetic isolation: a fast and reliable technique. Tissue Antigens 1986;28:301-12.

15 Persson L-Â, Carlgren G. Measuring children's dietsevaluation of dietary assessment techniques in infancy and evaluation of dietary assessment techniques
childhood. Int f Epidemiol 1984;13:506-17.
16 Fällström SP, Kristiansson B, Ryd W. Histological studies of small intestinal biopsies from infants with low rate of weight gain. Acta Pathol Microbiol Scand 1981;89(sect A): $431-8$

17 Ascher H, Hahn-Zoric M, Hanson LÅ, Kilander A, Nilsson L-Å, Tlaskalová H. Value of serological markers for clinical diagnosis and population studies of coeliac disease. Scand $\mathcal{F}$ Gastroenterol 1996;31:61-7.

18 Nilsson L-Å. Gliadin antibodies. In: HU Bergmeyer, ed. Methods of enzymatic analysis. 3rd Ed. Weinheim: VCH, 1986:214-23.

19 Bürgin-Wolff A, Gaze H, Hadziselimovic F, et al. Antigliadin and antiendomysium antibody determination for coeliac disease. Arch Dis Child 1991;66:941-7.

20 Walker-Smith JA, Guandalini S, Schmitz J, Shmerling DH, Visakorpi JK. Revised criteria for diagnosis of coeliac disease. Report of Working Group of European Society of Paediatric Gastroenterology and Nutrition. Arch Dis Child 1990;65:909-11.

21 Holmes GKT. Long-term health risks for unrecognized coeliac patients. In: Auricchio S, Visakorpi JK, eds. Common food intolerances I: epidemiology of coeliac disease. Basle: Karger, 1992:105-18.

22 MacDonald W, Dobbins W, Rubin C. Studies of the familial nature of celiac sprue using biopsy of the small intestine. $N$ Engl f Med 1965;272:448-56.

23 Gardiner A, Mutton K, Walker-Smith J. A family study of coeliac disease. Aust Paediatr f 1973;9:1 8-24

24 Mylotte M, Egan-Mitchell B, Fottress P, McNicholl B, McCarthy C. Family studies in coeliac disease. $Q \mathcal{F} \mathrm{Med}$ 1974;43:359-69.

25 Shipman R, Williams A, Key. R, Townley R. A family study of coeliac disease. Aust N Z F Med 1975;5:250-5.

26 Stokes P, Ferguson R, Holmes G, Cooke W. Familial aspect of coeliac disease. $Q \mathcal{F}$ Med 1976;45:567-82.

27 Stern M, Bender S, Gruttner R, Posselt H, Strobel S. Serum antibodies against gliadin and reticulin in a family study of coeliac disease. Eur F Pediatr 1980;135:31-6.

28 Ellis A, Evans D, McConnell R, Woodrow J. Liverpool coeliac family study. In: McConell R, ed. The genetics of coeliac disease. Lancaster: MTP Press, 1981:265-86.

29 Rolles C, Kyaw-Myint T, Wai-Kee S, Anderson C. The familial incidence of asymptomatic coeliac disease. In: McConell R, ed. The genetics of coeliac disease. Lancaster: MTP Press, 1981:235-44.

30 Sagaro E, Jimenez N. Family studies of coeliac disease in Cuba. Arch Dis Child 1981;56:132-3.

31 Stenhammar L, Brandt A, Wågermark J. A family study of coeliac disease. Acta Paediatr Scand 1982;71:625-8.

32 Auricchio S, Mazzacca G, Tosi R, Visakorpi J, Mäki M, Polanco I. Coeliac disease as a family condition: identification of asymptomatic patients within family groups. Gastroenterol Int 1988;1:25-31.

33 Holm K, Mäki M, Savilahti E, Lipsanen V, Laippala P, Koskimies S. Intraepithelial $\gamma / \delta$ T-cell-receptor lymphocytes and genetic susceptibility to coeliac disease. Lancet 1992;339:1500-3.

34 Mearin M, Biemond I, Peña AS, et al. HLA-DR phenotypes in Spanish coeliac children: their contribution to the understanding of the genetics of the disease. Gut 1983;24: 532-7.

35 Lin HJ, Rotter JI, Conte WJ. Use of HLA marker associations and HLA haplotype linkage to estimate disease risks in families with gluten-sensitive enteropathy. Clin Genet 1985;28:185-98

36 Kagnoff $M$. Role of environmental and genetic factors in celiac disease. In: Branski D, Rozen P, Kagnoff M, eds. Gluten-sensitive enteropathy. Basle: Karger, 1992:15-28.

37 Auricchio S, Follo D, de Ritis G, et al. Does breast feeding protect against the development of clinical symptoms of celiac disease in children? F Pediatr Gastroenterol Nutr 1983; 2:428-33.

38 Greco L, Auricchio S, Mayer M, Grimaldi M. Case control study on nutritional risk factors in celiac disease. 7 Pediatr Gastroenterol Nutr 1988;7:395-9.

39 Andersson H, Björkman A-C, Gillberg R, Kastrup W, Mobacken H, Stockbrügger R. Influence of the amount of dietary gluten on gastrointestinal morphology and function in dermatitis herpetiformis. Hum Nutr: Clin Nutr 1984; 38C:279-85.

40 Greco L, Mayer M, Grimaldi M, Follo D, De Ritis G, Auricchio $S$. The effect of early feeding on the onset of symptoms in celiac disease. $f$ Pediatr Gastroenterol Nutr 1985;4:52-5.

41 McCarthy CF, Mylotte M, Stevens F, Egan-Mitchell B, Fottrell PF, McNicholl B. Family studies on coeliac disease in Ireland. In: Hekkens WTJM, Peña AS, eds. Coeliac disease. Leiden: Stenfert Kroese, 1974:311-9. 